University at Buffalo School of Law

Digital Commons @ University at Buffalo School of Law

1984

\title{
Notes Toward an Intimate, Opinionated, and Affectionate History of the Conference on Critical Legal Studies
}

John Henry Schlegel

University at Buffalo School of Law

Follow this and additional works at: https://digitalcommons.law.buffalo.edu/journal_articles

Part of the Law and Society Commons, Legal History Commons, and the Legal Theory Commons

\section{Recommended Citation}

John H. Schlegel, Notes Toward an Intimate, Opinionated, and Affectionate History of the Conference on Critical Legal Studies, 36 Stan. L. Rev. 391 (1984).

Available at: https://digitalcommons.law.buffalo.edu/journal_articles/457

\section{C) ${ }_{\text {COPYRIGHT }}^{\text {N }}$}

This Article is brought to you for free and open access by the Faculty Scholarship at Digital Commons @ University at Buffalo School of Law. It has been accepted for inclusion in Journal Articles by an authorized administrator of Digital Commons @ University at Buffalo School of Law. For more information, please contact lawscholar@buffalo.edu. 


\title{
Notes Toward an Intimate, Opinionated, and Affectionate History of the Conference on Gritical Legal Studies
}

\author{
John Henry Schlegel*
}

When asked to write a history of the post-war years at Columbia as part of a proposed, but unexecuted, memorial to Herman Oliphant, Underhill Moore politely declined with the following observation:

If the history of the Columbia Law School of the 20's were written as a political analysis of a microcosm and if the personalities were snappily sketched, the history would be fun to write but not to have read. Such a history would have to be the work of a very old man in retirement, and then the manuscript would have to be deposited in a safe deposit box. ${ }^{1}$

I hold no such compunctions, but, at the same time, the notion of my writing the history of an organization now about seven years old, as I have been asked to do by this Review, is clearly ridiculous. Not because I lack perspective; no, that historian's ploy is a polite excuse for not saying mean-tempered things about living people. But first, because the notion of history implies a past that is to be recreated, and this organization effectively has no past; second, because, by virtue of

* B. 1942. B.A. 1964, Northwestern University; J.D. 1967, University of Chicago. Teaching Fellow 1967-68, Stanford University. Attorney 1968-73, Legal Aid Society of Chicago. Assistant Professor 1973-77, Associate Professor 1977-79, Professor 1979, Associate Dean 1982, State University of New York, Buffalo. This piece is dedicated to the late Grant Gilmore who, though he surely disliked the Conference and much of what it stands for, shared with its members a fierce determination to speak the truth as he saw it without regard to fad, fashion, or the sensibilities of the audience. I would like to thank Duncan and David for the time they spent attempting to help me understand their place in the organization of the Conference. Alan, Robert, Fred, Janet, Rand, and Mark each in his or her own way tried to keep me from saying stupid, offensive things. The quality of their advocacy should not be faulted for their collective lack of success, nor should the resulting product be attributed to any oversight on their part; these pages reflect only my own pigheadedness.

1. Letter from Underhill Moore to Hessel Yntema (Feb. 24, 1941) (Underhill Moore Papers, Sterling Library, Yale University). 
previous printed indiscretions, ${ }^{2}$ I cannot take refuge in that kind of bland institutional history that can be written about any organization at any time; and third, because I refuse to write, nor would the Conference allow me to write, authorized history of any kind. Thus, debarred from both serious and trivial scholarship, all I can do is leave a few footfalls, Lucy-like, should there pass by later a historian who cares about this movement. What follows is just that, a few clues that otherwise might be missed that hopefully will illuminate the formation, problems, and the place in the history of legal education of that comparative may-fly of legal organizations-the Conference on Critical Legal Studies (CCLS).

It is impossible to understand the organization of the CCLS without focusing on the friendship of two individuals-Duncan Kennedy ${ }^{3}$ and David Trubek. ${ }^{4}$ Kennedy is a cross between Rasputin and Billy Graham. Machiavellian, and with a gift for blarney that would make the stone get up, walk over, and kiss him, he can work an audience or an individual with the seductiveness of a revivalist preacher, for Kennedy wants your soul. Trubek, on the other hand, the selfdescribed leader of the Radical Yale Law School in Exile "Mafia," is more like a cross between Lloyd Cutler and Rabbi Ben Ezra. Enormously skilled at bureaucratic maneuvering (he has almost singlehandedly kept the soft money heat pump flowing at Wisconsin for several years now) and a naturally diplomatic conciliator of no mean talents, he makes and maintains alliances with consummate ease. One need not, however, defend one's soul against Trubek's onslaught; he mostly wants your support.

2. See Konefsky \& Schlegel, Mirror, Mirror on the Wall: Histories of American Law Schools, 95 HARV. L. REV. 833 (1982).

3. B. 1942. B.A. 1964, Harvard University; LL.B. 1970, Yale University. Law Clerk 1970-71, Justice Potter Stewart. Professor, Harvard University. The biographical information provided in this footnote and hereinafter has been, for the most part, taken from DIRECTORY OF LAW TEACHERS, 1982-1983 (1982).

4. B. 1935. B.A. 1957, University of Wisconsin; LL.B. 1961, Yale University. Law Clerk 1961-62, Judge Charles Clark; Attorney-Adviser 1962-64, Agency for International Development; Assistant Professor 1966-67, Associate Professor 1967-73, Yale University; Professor 1973, University of Wisconsin.

5. This mystical presence consists of a group of scholars, no longer appropriately described as young, all of whom were in one way or another seen as "left," and all of whom were denied tenure within a few years of each other at Yale. Besides Trubek, the most obvious mafioso is Richard Abel, now at UCLA and also a CCLS member. The four others who might or might not object to their inclusion in this group are Lee Albert, now at Buffalo; John Griffiths, now at the University of Groningen in the Netherlands; Robert Hudec, now at Cornell; and Larry Simon, now at USC. 
Trubek, who was Kennedy's first-year property teacher, was at Yale as part of the Law and Modernization program, the last gasp of law and social science at Yale. Kennedy participated in a Law and Modernization study group/seminar that Trubek and others organized and did some work related to the program before dutifully accepting a Supreme Court clerkship. The two passed quite easily from student and teacher to just good friends. Each in a sense was and is an "Enfant"-Kennedy, for his wonderfully jargoned, foultempered Polemic against the Yale Law School; ${ }^{6}$ Trubek, for his antiestablishment teaching and scholarship that made him a victim of the most recent ritual slaughter of the innocents at Yale, the event that led to the formation of the Mafia.

Debarred, it is said, from seeking a job at Yale because of the Polemic, Kennedy returned to Cambridge; Trubek left for Madison. While thus in exile, each undertook a short intellectual journey in disaffection from Law and Modernization. Trubek's self-estrangement is recorded elsewhere. ${ }^{7}$ He gave up faith in the positive, progressive role of law in developing countries, ${ }^{8}$ but never gave up faith in social science; indeed, he turned to Weberian sociology because of an aversion to Orthodox or "Scientific" Marxism of the "labor theory of value/ownership of the means of production/base determines the superstructure" variety. ${ }^{9}$ Kennedy, equally averse to Scientific

6. Kennedy, How the Law School Fails: A Polemic, 1 Yale Rev. L. \& Soc. Action 71 (1970).

7. Trubek \& Galanter, Scholars in Self-Estrangement: Some Reflections on the Crists in Law and Development Studies in the United States, 1974 Wis. L. REV. 1062 (1974).

8. And thus in this country as well, for the concert of foreign travel and domestic consequences is ancient.

9. Here a bit of disjargon, if that is possible, may be helpful to some readers. Since the twentics, Marxists-that is, individuals whose politics are to the left of liberal and who take as their starting point for analysis some part or parts of the writings of Karl Marx-may be broadly, if somewhat unfairly, divided into two groups-the Scientific Marxists and the Critical Marxists. The Scientific Marxists emphasize the following notions: the labor theory of value-that the value of a good is determined by the amount of labor utilized in producing it, and that the capitalist who pays the worker less than the full value of his labor is expropriating the "surplus"; the determinative importance of the class based ownership of the means of production; and the determination of the content of political, legal, and other ideas (the superstructure) by the social relations and structures (the base) that follow from ownership of the means of production. It is, quite wrongly, associated in the common mind with the fifties' stereotype of communist thought generated by the "they're all over the State Department/ better dead than red" school.

Critical Marxism draws its name from a group of scholars that included Theodor Adorno, Max Horkheimer, Herbert Marcuse, and others associated with the Frankfurt Institute for Social Research. See generally M. Jay, The Dialectical Imagination (1973). This school stresses the indeterminacy of social circumstances, and thus, the impossibility of deriving intelligible laws of historical change, economic or otherwise. While Critical Marxists do 
Marxism, began writing madly (his unpublished manuscripts, most notably on the Hart and Sacks materials, but also on classical legal thought, are at times all the rage) in what can only be described as the "Critical" or "Revisionist"10 Marxist vein.

The importance of this simultaneous movement for the structure of CCLS cannot be overemphasized. While the two kept their basically "left" politics, from a vaguely common intellectual enterprise, Trubek moved to a position of pessimism while Kennedy gravitated toward a different kind of explanation of the universe. Thus, Trubek's sociology emphasized the importance of matters of material culture for the form and content of law while Kennedy's antisociology began to stress the radical indeterminacy, and thus the unimportance, of material culture as an explanation of law. Kennedy sought instead to explain the form and content of law by reference to the internal dynamics of doctrine and to political theories about law. Thus, the two by themselves created a dynamic that has infected the organization they spawned, the Conference, from the first. Ironically, the dynamic is a wonderfully classical pattern of student/child turning the tables on teacher/parent with the taunt, "All you taught me was horse shit, just as I thought!" only to be told in reply, "No, no, you don't understand."

This reversal of roles-student impatiently instructing teacher and, in particular, "crazies" (as Kennedy likes to call them) denouncing as meaningless the efforts of empirical social science-not only has been replayed at every meeting of the group, but is the centerpiece of Kennedy's recounting of the group's formation in 1976-77. Soon after Kennedy's tenure, as Kennedy tells the story, Trubek, on a visit to Boston, remarked on the importance of the growing, newly secured leftist presence at the Harvard Law School and proposed a meeting between it and the older group of law and social science advocates. This latter group, of whom Lawrence Friedman, ${ }^{11}$ Philip

not deny the labor theory of value, and surely desire a change in the ownership of the means of production, they deemphasize the importance of these notions for understanding social and intellectual life. In particular, they reject the distinction between base and superstructure. Instead, they view alienation, ideology, historical contingency, and the role of human agency in history together with the relations of production as conceptually separable (though in fact inseparable) parts of the total sociocultural matrix of capitalism. For further discussion of this distinction, as well as a fascinating argument that the internecine warfare between these two groups is a socially determined argument over the primacy of different aspects of the Marxist canon, see A. GouldNer, The Two Marxisms (1980).

10. The choice of characterization depends upon one's predilections. To Scientific Marxists, the enemy is charitably viewed as "Critical," or uncharitably as "revisionist."

11. B. 1930. B.A. 1948, J.D. 1951, LL.M. 1953, University of Chicago. Private Practice 
Selznick, ${ }^{12}$ and Philippe Nonet, ${ }^{13}$ were taken to be central representatives, had, through the Law and Society Association and its Journal, kept flickering the faint candle of law and social science research and teaching in the law schools for at least twenty years. A self-proclaimed voice crying out in the wilderness of doctrinal teaching and scholarship, the group was academically left and, to a certain extent, politically left as well.

The point of hooking up with the law and social science crowd can be seen both as emphasizing the convergence between the two groups in their opposition to traditional law school teaching and scholarship and as beginning a Critical dialogue about the assumptions underlying the law on the books, law in action paradigm of the law and society group. At the same time, of course, Kennedy and his friends could also draw attention to themselves by saying in effect, "Hey we made it; there's another leftie on the block. You gotta take us into account now!"- $-a$ not insignificant objective given the politics of scholarship. This theme-the relationship between two aspects of dissident legal scholarship and teaching-can even be seen in the call for the first meeting, which referred to Kennedy and his friends as those who are "intellectually indebted . . . [to Trubek and his law and social science friends] yet have chosen a path quite different from that of their teachers."14 It may even explain that note of stridency in some CLS scholarship - a combination of frustration at the obtuseness of one's elders, a demand to be recognized, and a slight unsureness about the truth of the matter stated.

The friendship between Kennedy and Trubek has shaped the group in another way as well. Looking at the list of the Conference's organizers, one sees that each is tied to one or the other, or to both. Richard Abel ${ }^{15}$ was a colleague and co-victim with Trubek at Yale,

1955-57. Chicago. Assistant Professor 1957-61, St. Louis University; Associate Professor 1961-65, Professor 1965-68, University of Wisconsin; Professor 1968, Stanford University.

12. B. 1919. B.S.S. 1938, City College of New York; M.A. 1943, Ph.D. 1947, Columbia University. Instructor of Sociology 1946-47, University of Minnesota; Assistant Professor 1947-52, University of California, Los Angeles; Associate Professor 1952-57, Professor 1957, University of California, Berkeley.

13. B. 1939. Docteur en droit 1961, Université de Liège, Belgium; Ph.D. 1966, University of California, Berkeley. Chargé de cours 1966-70, Université de Louvain, Belgium; Assistant Professor of Sociology 1966-71, Associate Professor 1971-77, Professor 1977, University of California, Berkeley.

14. Letter from Mark Tushnet to Dear Colleague (Jan. 17, 1977).

15. B. 1941. B.A. 1962, Harvard University; LL.B. 1965, Columbia University; Ph.D. 1974, University of London. Assistant Professor 1968-70, Associate Professor 1970-74, Yale University; Professor 1974, University of California, Los Angeles. 
and along with Tom Heller, ${ }^{16}$ was a member of the Law and Development Study Group there. Rand Rosenblatt ${ }^{17}$ and Mark Tushnet ${ }^{18}$ started as first-year students with Kennedy, who, because the other two were pursuing joint degrees, ended up their senior editor on the Law Review. Tushnet, Heller, and Stewart Macaulay ${ }^{19}$ were colleagues of Trubek's at Wisconsin; Morty Horwitz ${ }^{20}$ and Roberto Unger $^{21}$ were colleagues of Kennedy's at Harvard. Similarly incestuous rings can be drawn to encompass most of the actual participants at the first meeting in the spring of 1977, where about the most tenuous connection was being "a friend of a friend" of one or the other. ${ }^{22}$

Even the destruction of the neat binary form that characterized the original conception of the organization can be attributed to Kennedy and Trubek. Tushnet was included on the organizing committee in large measure because, at the time, he was the Associate Dean at Wisconsin and, as such, had a secretary and easy access to duplicating facilities and other amenities without which organizing a large meeting is impossible. But Tushnet was then what he is not now-a relatively orthodox, Scientific Marxist. Thus (somewhat ironically for Kennedy's social indeterminist position), out of material necessity, a third leftist perspective achieved prominence in the group. It

16. B. 1944. B.A. 1965, Princeton University; LL.B. 1968, Yale University. Fellow 1968-70, International Legal Center, Bogota, Colombia; Fellow in Law and Modernization 1970-71, Yale University. Assistant Professor and Associate Professor 1971-79, University of Wisconsin; Visiting Associate Professor 1978-79, Professor 1979, Stanford University.

17. B. 1945. B.A. 1966, Harvard University; M.Sc. 1967, London School of Economics and Politica1 Science; J.D. 1971, Yale University. Law Clerk 1971-72, Judge Jack Weinstcin; Staff Attorney 1972-73, Health Law Project, Pennsylvania. Assistant Professor 1973-75, Rutgers University, Newark; Assistant Professor 1975-76, Associate Professor 1976-82, Professor 1982, Rutgers University, Camden.

18. B. 1945. B.A. 1967, Harvard University; J.D. 1971, M.A. 1971, Yale University. Law Clerk 1971-72, Judge George Edwards; Law Clerk 1972-73, Justice Thurgood Marshall. Assistant Professor 1973-76, Associate Professor 1976-79, Professor 1979-81, University of Wisconsin: Professor 1981, Georgetown University.

19. B. 1931. A.B. 1952, LL.B. 1954, Stanford University. Law Clerk 1955-56, Judge William Denman. Instructor 1956-57, University of Chicago; Assistant Professor 1957-60, Associate Professor 1960-65, Professor 1965. University of Wisconsin.

20. B. 1938. A.B. 1959, Gity College of New York; Ph.D. 1964, LL.B. 1967, Harvard University. Law Clerk 1967-68, Judge Spottswood Robinson, III. Charles Warren Fellow 1968-70, Assistant Professor 1970-74, Professor 1974, Harvard University.

21. B. 1947. Mr. Unger neither maintains nor circulates a vita. Other information is thus unavailable.

22. I offer but one example, a personal one. I was invited first as a friend of Al Katz, with whom I had taught at Buffalo. Katz and Kennedy had become friends as a result of a visit Kennedy had made to Buffalo, using Trubek's friendship with Marc Galanter as an entree. I was also invited as an acquaintance of Kennedy, whom I met when he came to Buffalo. 
is this third perspective, I suspect, that seems to overpower the social science at the root of the organization, making it appear to those on the outside to be a Marxist monolith. Yet nothing could be further from the truth. Indeed, for those on the inside, the addition of this third perspective has generated a second basic dynamic within the organization-three-corner catch.

The game goes pretty much as follows. While there are exceptions (Rick Abel, for instance) most of the law and social science dissidents who inhabit the Conference have not been heavily influenced by Scientific Marxism. Indeed, to the extent that they are Weberian; scholars like Trubek, Marc Galanter ${ }^{23}$ (for a short while a participant in the group), or Stewart Macaulay can be seen as anti-Marxist. Because the kind of thought that Kennedy may be taken to represent likewise rejects orthodox Marxism, the two groups have, and are able to mobilize, a common interest in attacking that enemy.

Yet that enemy is not without its own resources. On the one side, Scientific Marxism has a potential ally in the social scientists, since in some sense, both explain the world with great emphasis on material culture. For both of these groups, then, Kennedy and his crazies provide a common enemy, since in its emphasis on the role of ideas in determining the content of law, Critical Marxism may be seen as an attempt to turn Hegel upside down again and thus create a traditional idealism, not unlike the idealism that is liberal thought. On the other side, Scientific Marxism has an ally in Critical Marxism, since, for both tendencies, the evil in the world is capitalism. For both brands of Marxism, then, empirical social science is a convenient whipping boy, because, as social science, it can be tied to the long history of apologetics for American society in which the gap between law in the books and law in action can be viewed merely as a call to work harder to perfect that society, rather than as a symptom of the deep crisis caused by capitalism and its liberal apologists. And thus around the room the ball is tossed. ${ }^{24}$

23. B. 1931. B.A. 1950, M.A. 1954, J.D. 1956, University of Chicago. Bigelow Teaching Fellow 1956-57, University of Chicago. Fulbright Scholar 1957-58, University of Dehli. Assistant Professor 1958-59, Stanford University; Visiting Assistant Professor 1959-60, Assistant Professor 1960-66. Associate Professor 1966-71, University of Chicago; Visiting Professor 1971-72, Professor 1972-77, State University of New York, Buffalo; Visiting Professor 1976-77, Professor 1977, University of Wisconsin.

24. Alternative explanations of the intellectual dynamics of the organization can be given, and indeed I have previously done so. See Letter from John Henry Schlegel to David Trubek (June 5, 1977), reprinted in 2 CCLS NEwSLETTER, Summer 1977. CCLS is clearly not a Marxist monolith, though to some outsiders the predominance of Critical perspectives in the most visible members of the group might indicate the contrary. David Trubek has re- 
Whether the resulting form of the game stabilizes or destabilizes the organization may be a question of perspective, but this is basically unimportant. Within the group and its scholarship, all three alliances can be seen. Indeed, the classic example comes from the very first meeting ${ }^{25}$ where, at the end of a session, Trubek attempted to sum up "the problem" with which the group had been grappling as "whether we are Marxists." He then announced his difficulty with the labor theory of value and thus his rejection of Scientific Marxism. Tushnet, unconsciously emphasizing the similarities of his own position with Trubek's, retorted that "the question" was not "whether we are Marxists," but whether, given that ideas can have some influence on material economic culture, we believe that "in the last instance" it is material culture that determines the content of those ideas. Having thus been pushed into the role of the opposition, Kennedy and his friends first responded by denying their allegiance to Scientific Marxism, calling instead for the "totalization of base and superstructure"- that is, the treatment of the world of material culture and the world of ideas as a totality, any piece of which is a representation of the whole, and neither part of which has an a priori claim to being determinative of the other part. They then, unconsciously no doubt, opened the door for the social scientists by stating that "the question" was how structures of thought legitimate the existing social order and the domination inherent in it-a vaguely sociological question, though not one on which quantifiable empirical research could be done. ${ }^{26}$ And thus the ball was back where it started, follow-

jected the proposition that the dynamic is a binary one, fluctuating between "subjective, idealist doctrinalist" and "resigned, objective, behavioralist" perspectives. See D. Trubck, Slaying Dragons or Creating Them? Preliminary Reactions to the First Conference on Critical Legal Studies (June 6, 1977) (unpublished manuscript). I think there is more to this distinction, which is basically that between Critical Marxists and other Marxists, than Trubek will admit. Such a view of the world reflects the dynamics of actual power in the group where the Critical perspective is the more prevalent, a fact that lcads factions making up the loyal opposition to emphasize the traditional materialism that they share At the time of the formation of the group, I argued for a two-by-two table-Marxist/non-Marxist, idealist/materialist-and for a binary structure-more emphasis on the determination of reality by the world of ideas/more emphasis on the determination of reality by the world of objects. See Letter from John Henry Schlegel to David Trubek, supra. Six years later, neither characterization seems to fit the group quite right. What the dynamic will be when the group attempts to integrate the feminist "rights" perspective in the next few years is anyone's guess.

25. To date, the group has had eight meetings: Madison, spring 1977; Boston, winter 1978 (said to be a regional meeting); Madison, fall 1978; San Francisco, spring 1979; Buffalo, spring 1980; Minneapolis, spring 1981; Boston, spring 1982; Camden, spring 1983. Clearly, the shift to annual meetings refiects the dawning understanding that, at least among legal academics, relatively little "new" work gets done, even in the course of a year.

26. It thus seems to me that Alan Hyde shows a misunderstanding of his subject when 
ing a dynamic that can be directly attributed to two men, Trubek and Kennedy, who brought their friends and acquaintances together to talk about law.

Of course when a group like this is formed, it in some sense always takes on a life of its own, apart from the wishes of its Founding Fathers; CCLS is no exception. In spite of their hopes and wishes for concord, agreement, and the prospect of "a new scholarly community," Trubek and Kennedy's design of the group led inexorably to the already described intellectual conflict, a conflict they feared and even tried to paper over during and after the very first meeting. ${ }^{27}$ Their design led to external conflict as well. Here the fear of conflict-social and in some ways intellectual-probably far exceeded its reality. In any event, the fear dominated the group, or at least the inner circle, from the outset. The shadow villains were two. The first, an unnamed, and, I suspect, an unknown, band of doctrinaire Marxists referred to as "Guild types," brought forth both fears-the social and the intellectual. It was assumed that, as was the case with much factional left politics during the late sixties and early seventies, intellectual disagreements would spill over into social relations, and clearly a good portion of the group wanted space, both intellectual and social, for anything but doctrinaire discussion and community fractionalization. The second, a group of prominent liberals, brought forth only the fear of intellectual conflict, for it was assumed that fights about liberalism within the group would inhibit development of the group's own distinctive approaches to law. ${ }^{28}$

At the first meeting these two groups were simply excluded. This strategy became so blatant with respect to the liberals that it led to an amusing conversation between Kennedy and Dean Harry Wellington of Yale. Dean Wellington first protested that members of his

he suggests that an "agnostic" position be taken on the legitimation function of law because the social science literature cannot quantitatively verify its independent operation. Sec Hyde, The Concept of Legztmation in the Sociology of Law, 1983 Wis. L. REv. 379. The concept is not directed at something countable but at a way of thinking about institutions in society. It would be equally plausible to take an agnostic position on the existence of a feudal world view because of an inability to verify its independent impact on the actions of serfs.

27. Ser, e.g. D. Trubek, supra note 24: Abel, Comments, 2 CCLS NEWSLETTER, Summer 1977.

28. There was also a trace of "small-pondism" in this fear: In the liberal pond, we were a small chorus of tree frogs: in our own, we are a more audible chorus of bull frogs. And it should not be forgotten that there was some joy at having an exclusive club of our own, given the way that more than a few CLS members had been treated by the liberal law school establishment. 
faculty, obviously as smart and as "with it" as any around, were being excluded for no good reason. He then retreated wholly satisfied, upon being informed that the criterion for extending invitations was not smarts but politics and that on this criterion the Yale faculty was not left enough. Ever since the original policy of "by invitation only" was changed to "open door" at the second, so-called "regional," meeting at Northeastern the following fall, traditional liberals have largely avoided the organization like the plague. But an incident at that meeting in which a paper by Ike Balbus ${ }^{29}$ was viciously, if rather isolatedly, attacked for having nothing to do with "the working class," seemed for some to suggest that the other exclusion had been sensible.

These fears, largely unrealistic though they may seem to most of us now, and to some of us then, given the implicit decision that the group was to be largely composed of, and directed by, the interests of the law professoriat, led to the quite astonishing highlight of the second Madison meeting in the fall of 1978. True to all the norms of left gatherings, CCLS ends each conference with a "plenary" session for feedback, planning, speeches, and making up. However, this plenary session began with a very embarrassed organizing committee informing the gathering that the heretofore informal group had become a membership organization with its own pledge and bylaws, and that an interim executive committee had been selected to run the organization until a board of directors with staggered terms, just like a corporate takeover target, could be elected. The silence from an audience accustomed to a modicum of self-determination in such matters was deafening, and the committee's defense of its action as providing for future democracy rang hollow when placed in conjunction with known, if not shared, fears of left factionalism.

Not only is the group thus given on occasion to the common liberal vice of putting institutions first and individuals second, but it also suffers from more than a dose of liberal elitism. One can see in the inclusion of the likes of George Fletcher and Ian McNeil at the first Madison meeting a need to have "names," which is less obvious in the inclusion of Roberto Unger on the organizing committee and in the hagiography of the organization, even though he has done little more than attend the first two meetings and deliver a long speech at a recent one. Less innocuous, though equally understandable, is

29. B. 1944. A.B. 1964, Colby College; Ph.D. 1970, University of Chicago. Assistant Professor 1969-73, Princeton University; Associate Professor 1973-76, City University of New York; Associate Professor 1976-83, Professor 1983, University of Illinois, Chicago. 
the pride of the group in general and the excitement of some of its members in particular at the establishment of its first "colony" at such an elite institution as Stanford, rather than at, say, Dayton, Duquesne, or Bridgeport. Similarly, the joy shared by the troops at any "news" suggesting even obliquely that a "fancy" school might be interested in getting a "Critical legal type" to add a touch of the exotic to its menu is notable, if only to cause wonder at the notion that demystification-the stripping away of the veneer of apolitical decisionmaking from the legal process-from the top down is a rational revolutionary strategy, a notion again called to mind every time one hears of left victories in the glacial march of curriculum and appointments reform at Langdell Hall. Less pleasant is the feeling, often expressed by newcomers, that the group is divided between an inner circle of old timers who dominate the organization and whose ideas and interests set its tone and direction, and a great unwashed whose presence is tolerated, but little more, unless introduced by the right people. This accusation gains some credence from the observation that it took three years before the organizing committee would open up "summer camp"- now annual week-long summer sessions devoted solely to discussion of selected texts and scholarship-to the membership generally, and even then only with group leaders carefully ensuring that the new guest list looked more than slightly like the old. ${ }^{30}$

Exactly what should be concluded about the organization and its members from all of this is by no means clear. No one could deny that endless hours have been spent discussing both institutional protectiveness and elitism in CCLS. And some progress has been made: Witness the recent decision to open up membership in the organizing committee to anyone who wishes to join in its deliberations. Furthermore, to complain about either institutional protectiveness or elitism is both to engage in the reification of democratic forms and to forget that people will be friends with, and trust the judgment of, those people whom they know best and longest. In a group that began at,

30. Summer camp began in the summer of 1980 with a meeting in Santa Cruz, jointly sponsored by the Conference and by Crown College of the University of California at Santa Cruz. Participants from Santa Cruz included Norman O. Brown, Richard Wasserstrom, and Hayden White. Subsequent meetings have been in Andover. I should emphasize that these meetings have been incredibly important for the intellectual development of some participants, and not simply an exercise in elite navel gazing. This fact may suggest that more effort should be put into sponsoring similar small working gatherings and less effort into organizing large national meetings which seem to be important to the intellectual development of very few people. 
and primarily with people from, elite law schools, some, perhaps much, of what is seen as elitism is nothing more than sticking with and trusting one's friends. Yet, in an organization that claims to be as deeply antihierarchical as this one does, behavioral manifestations of traditional notions such as "wisdom proceeds up river on the Charles and then out to the countryside," or "getting ahead is teaching at a better law school," are deeply troubling. Such notions abet nagging doubts in the membership and deeply held suspicions in outsiders that what the group is about is little more than shifting power from one elite to another. That is not what the group is about! Yet old ways, bred in the bone early enough to fit Loyola's boast, die much harder than grows the rhetoric that denies their existence. Unfortunately, this truth has not yet fully reached the left-handed consciousness of the collective dictatorship that runs the organization.

One should not, however, surmise that this informal politburo has had a profoundly negative impact on the group. In fact, precisely the opposite is the case. The group as a whole has fostered within its self-defined borders an incredible tolerance, both social and intellectual, which allows individuals to make quite silly statements in open meetings, and allows newcomers, at least those who are a bit aggressive, simultaneously to acquire a supportive yet Critical forum for ideas and an equally supportive social network. In such a community, fragmented though it may be, personalities have grown with the luxuriance of houseplants. No meeting would be complete without the appearance of Peter Gabel's ${ }^{31}$ curly black locks and earnest, terminally tired eyes, to present, in his own wonderfully dense and contorted prose, the epicycles of self-alienation as he has come to understand them in any given year. ${ }^{32}$ Nor would I ever miss the balding, almost elfin, Morty Horwitz, embarrassedly defending his latest attempt to salvage his limited version of the socioeconomic

31. B. 1947. A.B. 1969, J.D. 1972, Harvard University. Teaching Fellow 1972-74. University of California, Berkeley; Assistant Professor 1974-75, University of Minnesota. Professor and Co-President 1975, New College of California School of Law.

32. Peter's verbal style has been captured best by a cartoonist at New College, whose piece, "Peter Talks to Some Winos" begins:

The central point of everything I have said thus far can be summarized as follows: the "legal system" is the institutionalization of the effort of alienated consciousness to maintain its own dominant position by channeling social conflict into authoritarian settings and by "resolving" this conflict according to a system of thought that reinstates the "legitimate necessity" of the status quo.

It is to Peter's credit that he immediately circulated this satire on his style among a number of people. Though the Conference prides itself on its seriousness, unlike most other parts of the law professoriate, it has the pronounced ability to laugh at itself on occasion. Peter is a classic example of this healthy human (and humane) trait. 
determinism of legal ideas from the onslaught of his neighbor in Langdell Hall, Mr. Kennedy. Similarly important are the cleanly polished sentences and paragraphs, always spiced with just enough humor to make the medicine go down, delivered in the most carefully modulated tones by Robert Gordon, ${ }^{33}$ words that are inevitably contrasted with the more direct utterances of that self-proclaimed "old fogie" where teaching is concerned, the stout Tushnet who, on occasion, sees fit to remind us that "when they find out what we're doing, they're going to come after us with guns." Such judgments of centrality to the experience are, of course, personal and idiosyncratic, but to build an organization in which the personal and idiosyncratic can flourish, where the group as a whole can on occasion discuss a book or idea and not sit ossified as presenters drone on and commentators sit nervously on their witticisms, is an achievement not to be sneered at.

Setting aside the organizational dimension of CCLS and returning to the intellectual, I would hazard a guess that the reference to the Frankfurt School of Critical Marxism in the title of the organization was probably lost on many, if not most, of the participants at the first meeting ${ }^{34}$ the majority of whom had read little of that or other Critical Marxism beyond the obligatory college volume of Eros and Civilization or One Dimensional Man. This fact, if such it be, suggests that, to date at least, the CLS movement may be less important as an event in the history of legal thought, than as an event in the history of legal education.

One of the most important, though virtually unexamined, aspects of legal education is its cultural one. At least since Blackstone, and I suspect long before, the central job of legal education has been to justify existing rules of law to the nascent members of the legal elite. ${ }^{35}$ The task is an important one; no society wants its priests wandering around doing their magic while doubting the one true faith. Here, then, can be appreciated the importance of "Langdell's" case method: It moved this act of justification closer to the center of the student/teacher relationship by turning what was oftimes, though

33. B. 1941. A.B. 1967. J.D. 1971, Harvard University. Assistant Professor 1971-74. Assuciate Professor 1974-77. State University of New York, Buffalo: Associate Professor 1977-80. Professor 1980. University of Wisconsin: Professor 1982. Stanford Lniversity.

34. David Trubek always says that "Critical" is meant to cover "anything from Marxist to querulous."

35. Here, and in much of the balance of this paragraph, I steal shamelessly, and probably erroneously, from Al Katz. 
not always, a monologue into something more approximating a dialogue, from a passive to a vaguely active enterprise.

While the style of this dialogue of justification seems to have changed over time, as well as within particular eras or even within particular law schools, its content has remained remarkably stable for the past one hundred years. In that period, there have been but two types of content. The first, whatever its claims to evolutionary historicism, justified the rules because of their logical interrelationship; the rules were right because they fit with the other rules. The second justified the rules because of their intrinsic social goodness; the rules were right because they embodied wise social policy. The first is said to be formalist; the second, more misleadingly, Realist. But whatever the content of the act of justification, the enterprise is by nature conservative, not radical. Its overt political content can, and has, varied from conservative to liberal, and might conceivably be reactionary or radical, but its basic conservatism remains. In order for all the nascent elite to sleep comfortably, the message must be positive. It need not be panglossian, but to be effective, the message cannot be that more than a few rules need fixing in order to get the system running right. Within this basic intellectual structure operates the history of legal education since 1870.

For the first fifty years the overt political content of the dialogue of justification was overwhelmingly conservative, so overwhelmingly conservative that Roscoe Pound's plea for an improved civil procedure $^{36}$ could indeed be seen as radical, which gained him instant notoriety in legal academe. The combination of the death of progressivism in World War I, the swing to a socially conservative national government, and the gathering economic dislocation that by the end of the twenties had become the Depression, brought to the fore renewed left political activity. In the legal academy this left politics joined with the twentieth century notion of science as empirical inquiry into a world "out there" to produce American Legal Realism.

Politically, Realism was no more than liberal; its content reflected much of what Mark Tushnet likes to call "the 1964 platform of the Democratic Party." 37 But the importance of its liberalism should not be underestimated, for as liberals, Realists were substantially to the left of the academic center, as evidenced by Llewellyn's dispute with

36. Pound, The Causes of Popular Dissatisfaction with the Administration of Justzce, 1906 A.B.A. REP. 403.

37. Tushnet, Deviant Science in Constitutional Law, 59 TEx. L. REv. 815, 815 (1981). 
Pound, ${ }^{38}$ who was left by law school standards but at best a political centrist. In contrast, Realism was educationally radical, for it denied that the rules as they existed were justified. Here again the Realists' differences with Pound are instructive. The basic thrust of Pound's position was that if the law in action were made to conform with the law in the books, all would be fine. But one of the thrusts of Realist scholarship was to suggest that the law in the books was not fine.

Realism made this assertion in four ways. The first is the most well known: Claims were made, often building on Hohfeld's work, ${ }^{39}$ that the rules were simply incoherent. Here, the most notable example is Walter Wheeler Cook's work on the conflict of laws. ${ }^{40}$ The second is less well known: Claims were made that justification was inappropriate to scientific inquiry. This strategy underlay all of the Realists' empirical research, but is most notable in the work of Underhill Moore. ${ }^{41}$ The third is now a classic: Attempts were made to simply debunk the process by which the rules were created. Here, Jerome Frank's work is most notable. ${ }^{42}$ And the fourth is the most unusual, but not unknown, strategy: Rather direct assertions were made that the rules were simply wrong. Here, Thurman Arnold ${ }^{43}$ and Walton Hamilton ${ }^{44}$ come to mind.

Given that Realism thus undercut the underlying purpose of legal education-the justification of existing laws-it not too surprisingly created a real flutter in the academy. And that flutter became downright hostility as the thrust of the Realists' critique of "justification through logical interrelationship" became clear to even the most opaque of humans by the late thirties. The reason for the hostility is easy to identify: The Realists' critique highlighted the central question that the dialogue of justification is designed to suppress: the question of power-in whose interest legal rules are made.

After a tangled history, of interest only to aficionados of the thirties and forties, a basic shift in the form and content of the dialogue took place. Policy analysis of a liberal political stripe became the

38. Llewellyn, A Realstic Jurisprudence-The Nexi Step, 30 CollM. L. REI. 431 (1930); Pound, The Call for a Realist Jurssprudence, 44 HARV. L. REv. 697 (1931); Llewellyn, Some Realwsm About Realssm-Responding to Dean Pound, 44 HARv. L. REv. 1222 (1931).

39. Hohfeld, Some Fundamental Legal Conceptzons as Applied in Judicial Rearoning, 23 YALE L.J. 16 (1913).

40. Cook, The Logical and Ligal Bases of the Confict of Laues, 33 YALE L.J. 457 (1924).

41. See, e.g., Moore, Rational Basis of Legal Institutions, 23 ColvM. L. Rev. 609 (1923).

42. J. Frank, LAW ANd the MODERn MIND (1930); Frank, Are Judges Human?, 80 U. PA. L. REY. 17 (1931).

43. Arnold, Criminal Altempts-The Rise and Fall of an Abstraction, 40 YALE L.J. 53 (1930).

44. Hamilton, The Anctent Maxim Caveat Emptor, 40 YALE L.J. 1133 (1931). 
norm, and questions of process were thought to have laid to rest questions of power. In the meantime, rising academic standards increasingly cut off access to legal careers for the lower middle class, and decreasing course requirements were turning law schools into a thoroughly incoherent garden of earthly delights.

This stasis was, however, relatively short-lived. By the mid- to late-sixties, the fallout from student and, with caterpillar-to-butterfly-like eventuality, teacher idealism concerning the New Frontier and the Great Society had begun to reach the law schools. This was then followed by disillusion and hostility arising from the Vietnam War, Watergate, and the nation's political shift to the right. Simultaneously came student clamor for relevance and clinical education and the assembly of a small but determined band of social science types dedicated to showing what was "really" going on out there, the Law and Society Association.

Meanwhile, inside the classroom, policy analysis was becoming an increasingly fragile enterprise. This fragility was probably an inherent problem, for the usual technique of such analysis-balancing of interests-transparently invites dissent in the form of "no, this interest is the stronger." With the collapse of "The End of Ideology" consensus during these years, such dissent vigorously increased both inside and outside the classroom. The result was that questions of power were again brought to the fore, if only to be hidden in embarrassment.

The growing awareness of the fragility of policy analysis made traditional legal scholarship appear more and more bankrupt in its attempt to maintain the appearance of neutral disinterestedness through the ad hocing of interests and the transparent manipulation of their weight. Even more tellingly, one could clearly discern among the more elderly members of the teaching fraternity a sense of general malaise and nostalgia for the "good old days" when standards were clear so that everyone knew what was good teaching and fine scholarship.

It is out of this unstable situation that CCLS emerged. Almost all of the principals of the group came to maturity during the late sixties or early seventies. Most began teaching during these years as well, often after a stint in legal services or some other reform-oriented post, as well as participation in the antiwar movement. ${ }^{45}$ And while dreams of reform faded, the common politics did not; indeed, many

45. I note with some alarm that a quick review of the biographies strung out in these footnotes reveals a consistent pattern of progression from fancy law school to fancy clerkship 
of the principals often moved farther left in an attempt to explain what had gone wrong with earlier great hopes.

The personal odyssey of the principals of CCLS does not have an obvious Realist analogue; yet the drawing of parallels between these two intellectual movements separated by nearly fifty years may nevertheless be appropriate, perhaps even illuminating, because of a shared, relatively left politics, practiced in a relatively conservative social and political environment. First, while the politics of most of the CLS group is much left of Realist politics, it, like Realist politics, is threatening to the dominant elements in legal education less because of its absolute position on the political spectrum than because it is left relative to those dominant elements; left is destabilizing. More important, however, just like Realism, CLS has as one of its central goals the dejustification of legal rules. Indeed, the movement uses essentially the same techniques; claims of incoherence or inappropriateness abound, as do examples of demythologizing (i.e., debunking or trashing) judicial decisionmaking (and everything else), and direct denials of the correctness of policy. And the reaction of horror from the established corners of legal academia, especially liberal academia, is much the same as well.

At the same time, one should note differences between the two movements, other than purely political ones. While there are exceptions in both groups, the social science of choice for Critical scholars is history, not the heavily quantified sociology that so fascinated the Realists. Likewise, claims of incoherence are less likely to be seen at the level of specific doctrines that the Realists loved to work over than at the level of entire subject areas of law- contracts, ${ }^{46}$ labor, ${ }^{47}$ civil rights, ${ }^{48}$ etc. Furthermore, concern with the specific proposals for law reform that often lay just beneath the surface of Realist scholarship is conspicuously absent from much of present Critical scholarship. On the other hand, Realist scholarship largely lacked the explicit concern for social theory that abounds in Critical scholar-

and back to fancy law school. I trust that this is but another example of data obscuring the facts, though it also occurs to me that this may be a point for the antimaterialist position.

46. See Gabel, Intention and Struclure in Contractual Conditions: Outline of a Method for Critical Legal Theory, 61 MinN. L. REı. 601 (1977); Mensch, Book Review. 33 StAN. L. Rev. 753 (1981).

47. See J. Atleson, Values and Assumptions in American Labor laW (1983); Klare, Judiczal Deradicalization of the Wagner Act and the Origins of the Modem Legal Consciousness, 1937-19.7J, 62 MI.NN. L. REv. 265 (1978); Stone, The Post-War Paradigm in American Labor Law, 90 Y ALE L.J. 1509 (1981).

48. See Freeman, Legittmizing Racial Discrimtnation Through Antidiscrimination Law: A Critical Retiew of Supreme Court Doctrine, 62 MinN. L. REv. 1049 (1978). 
ship. And while both movements share a concern with legal education, it remains to be seen whether Critical scholars can transform the face of legal education as effectively as the Realists managed to do.

This detour into what some of the group might call a portion of the World-Historical Process now needs to be brought back to the details that are, and have shaped, the Conference. The attack on social science at the first meeting (and ever since) was so strong that it brought an almost bitter, fifties-like denunciation from a soul as calm as Marc Galanter, and a more resigned, "I think I am not wanted here," from Joel Handler. ${ }^{49}$ The result has been that the social science post in the game of three-cornered catch has been weak, personed primarily by David Trubek and Stewart Macaulay, the latter whose native Bah Humbugry makes him at best a fellow traveller. Consequently, the stoutest defense of social science often comes from the historians and others in the group interested in social and cultural history. This assault on social science has also meant that the rapprochement Trubek and Kennedy sought with the law and social science group has been a conspicuous failure; in fact, the mandarins of the Law and Society Association have responded with bitter denunciations of the "new doctrinal barbarians." And this problem has surely not been helped by Tushnet's wonderfully, or awfully (take your pick), foul-tempered review of Lawrence Friedman's History. ${ }^{50}$

On a more positive note, the quite tentative, very cliquish, even conspiratorial, beginning of the Conference seems to have passed. No more is one likely to find, as was the case at the first meeting, Peter Gabel and Alan Freeman ${ }^{51}$ smoking big black cigars in one secluded corner of David Trubek's yard, while Trubek and Roberto Unger, seated in a peacock chair, in another secluded corner talked South American politics, often in Spanish (or was it Portuguese?). No more do strangers to the group, suffering from nothing more dangerous than an understandable modicum of insecurity in new sur-

49. B. 1932. A.B. 1954, Princeton University; J.D. 1957, Harvard University. Assistant Professor 1961-62, Vanderbilt University; Assistant Professor 1962-64, University of Illinois; Professor 1965, University of Wisconsin.

50. Tushnet, Perspectives on the Development of American Law: A Critical Review of Fredman's "A History of American Law", 1977 WIS. L. REv. 81.

51. B. 1943. A.B. 1964, Brown University; LL.B 1967, New York University. Law Clerk 1967-68, Judge Edward Weinfeld. Attorney-Adviser 1968-71, Office of General Counsel, Department of the Air Force. Associate Professor 1971-74, Professor 1974, University of Minnesota; Professor 1981, SUNY/Buffalo. 
roundings, seem to be "Stalinist" or "too intense." Instead, the group has become incredibly friendly, even clubby. Thus, once the perfectly silly embarrassment wears off about how little scholarship the group as a whole, except for Tushnet, has produced in a year, annual meetings become much like the gathering of a clan. And that is good.

The aging of the group, with the accompanying proliferation of children whose appearance at these meetings may signal, if ever so softly, a possible hairline crack in the bourgeois separation of work and family, of course adds to the clannishness. Thus, trading pictures of one's children is by no means an unknown behavior, and a threat to the tenure of, or a decline in the health of, a member is a matter of more than a little seriousness. Similarly, the absence from any gathering of, say, Alan Freeman, whose manic energy and relentless optimism has surely infected everyone, as well as nearly wiping out his health, or Karl Klare, ${ }^{52}$ a wonderful combination of high seriousness and warm, open goodwill, or Rand Rosenblatt, whose bald Lenin-like profile gives the impression of a fierceness that is simply nowhere to be found in his humane inside, will not only be noted, but actually counted against the success of the event.

But clannishness can have its downside, too. When missionaries like Kennedy or Klare turn out hundreds of locals for a meeting of a group whose core membership is no more than one hundred, the result is predictable. The old people, myself included, spend time grumping about, wondering "Who are all these people," until finally spotting a few old friends; then the hugs, kisses, and handshakes start. Only thereafter, when such by no means insignificant formalities are out of the way, can the serious business of the group, welcoming the newcomers and introducing the members to them, both socially and intellectually, begin in earnest.

Equally positive is the support the group has provided for young, largely isolated, scholars scattered over the country in hostile places. ${ }^{53}$ Much of this support has come by providing protective col-

52. B. 1947. B.A. 1967, Columbia University; M.A. 1968, Yale University; J.D. 1975, Harvard University. Staff Attorney 1975-76, National Labor Relations Board, Boston; private practice 1976-77. Boston. Associate Professor 1977-80, Professor 1980, Northeastern University.

53. I submit as evidence of the hostility of the liberal law school world a long discussion I had with Alan Freeman about the first meeting of the Conference. As he experienced it, the first issue on the table was liberal vs. radical; the second, empiricist vs. nonempiricist, and the third, Critical Marxist vs. other Marxist. Given the nature of the invitations to that first meeting, the first issue was decided before the doors were open and the last unavailable. That 
oration, by making left legal scholarship okay - weird but not dangerous (or is it the other way around?). And in so doing, the group has succeeded in what Trubek remembers as another of the Founding Fathers' intentions. Less successful have been attempts to involve practitioners who share a common politics in the organization. Some came even after the second Madison conference, at which many felt they were read out of the organization, but few, other than David Kairys, ${ }^{54}$ who proves the rule by taking up legal scholarship, and clinicians like Garry Bellow ${ }^{55}$ and Jeanne Charn, ${ }^{56}$ have stayed. The mismatch is obvious: Practice is only tangentially relevant to a group largely engaged in dejustifying rules, for examining the law in action is only a variation on the other CLS techniques for achieving that end.

More encouraging is the recent explosive growth of a serious feminist presence in the group. Its delayed appearance may have something to do with the late reception of women into the ranks of law school teaching, an acceptance that today, even at the best of places, tends to be partial, if not carefully monitored. But whatever the reason, this presence, dominated as it is with a heavy legal rights analysis and agenda, cannot but alter an organization that has until now eschewed such an approach to law in favor of grander social theory and explanation.

A good story has a beginning, a middle, and an end. Critical Legal Baloney, as some of us fondly call it, has at best a beginningat Pasquina's Coffeehouse on Harvard Square, so I am told. Beyond its beginning it has only people, people sharing a common politics that convinces them that existing rules of law are not justifiable. If the liberal conceit continues to unravel, and all concerned become aware that the postulated dichotomy between the public sphere of

either issue was even seen as alive is a reflection of the battle back at Minnesota. Nor was this misperception an isolated quirk of Alan's mind; others must have shared it with him. Tellingly, those who correctly perceived the second issue as the only live one at that meeting came from relatively less isolated environments-Buffalo or Wisconsin.

54. B. 1943. B.S. 1965, Cornell University; J.D. 1968, Columbia University; LL.M. 1971, University of Pennsylvania. Private practice 1971, Philadelphia.

55. B. 1935. B.A. 1957, Yale University: LL.B. 1960, Harvard University; LL.M. 1961, Northwestern University. Director 1962-65, Legal Aid Agency for the District of Columbia. Associate Professor 1968-71, University of Southern California; Visiting Professor 1971-72, Professor 1972, Harvard University.

56. B. 1944. A.B. 1967, University of Michigan; J.D. 1970, Harvard University. Staff Attorney 1970-71, Community Legal Assistance, Cambridge, Massachusetts. Assistant Dean 1973-77, Lecturer and Research Associate 1977-79, Harvard University. Director 1979, Legal Services Institute, Jamaica Plain, Massachusetts. Lecturer 1982, Harvard University. 
politics and the private sphere of law is fraudulent-that, in a phrase, LAW IS POLITICS, pure and simple-then the movement and its visible organ, the Conference, may be of some significance in the world. If not, if it remains a group of individuals providing each other with tremendous mutual support in a world seen to be basically hostile towards them, if it ends up only a "lonely hearts club for left-wing law professors," 57 then it will still be important, maybe even more so.

57. The phrase comes from Cappy Silver. B. 1955. A.B. 1978, Hampshire College. A paralegal welfare advocate and antinuclear organizer who decided not to become a lawyer, she is now an actress and singer with the progressive rock band, Balance of Power. 
